\title{
CORRECTIONS
}

\section{Migrants' healthcare: who pays?}

In the figure of this Feature article by John Appleby ( $B M J$ 2013;347:f6483, doi:10.1136/bmj.f6483), we inadvertently referred to British people who no longer live in the UK as ex-patriots. We meant expatriates.
Cite this as: BMJ 2013;347:f6640

๑ BMJ Publishing Group Ltd 2013 